\title{
Research on the Development Path of Commercial Banks under the Influence of Internet Finance: Taking P2P Finance as the Example
}

\author{
Xin $\mathrm{Yu}^{1}$ \\ ${ }^{1}$ Xi'an International University, \\ Xi'an 710077, China
}

\begin{abstract}
In this paper, we conduct research on the development path of commercial banks under the influence of Internet finance. With China's accession to the world trade organization and the rapid development of domestic e-commerce, Internet finance faces the great challenge of international. With the current commercial banks to carry out the business has obvious overlap, there is a certain substitution effect. There are no doubt commercial banks how to deal with the challenge of Internet finance is a major issue. Our research provides the suggestions of advancement for the traditional commercial banks to enhance their ability of making profits which will be meaningful.
\end{abstract}

Keywords: Commercial Banks; Internet Finance; P2P Financial; Reform and Update.

\section{Introduction}

Internet financial innovation on the traditional financial pattern, to a large extent make up for the defects of traditional financial industry, bring great convenience to customers, tremendous business opportunities for practitioners as well as the present situation of the domestic small and medium-sized enterprise financing difficult bring certain change. With China's accession to the world trade organization and the rapid development of domestic e-commerce, Internet finance faces the great challenge of international. Therefore, the accurate analysis of the relationship of Internet finance and traditional finance is the key to keep our country financial industry continued upward. The rapid development of Internet financial has affected the liability business of commercial banks, and has a tendency to make pay the intermediary function marginalized, a major threat to intermediary business of commercial bank. For example, Internet financial companies provide pay-and-escrow. Products have been able to provide for the customer payment receipt and payment, transfer the remittance, telephone bill and insurance pay, settlement and payment services. With the current commercial banks to carry out the business has obvious overlap, there is a certain substitution effect. There is no doubt that commercial banks how to deal with the challenge of Internet finance is a major issue. Internet financial started relatively late, development of domestic road twists and turns, even if many awards obtained international network bank in China in recent years, but the financial crimes are still common. The development of the Internet financial must possess a complete set of regulatory and the legal system, implement real-name authentication and establish compatible personal credit system.

In general, the Internet financial development model could be separated into the following parts. (1) Enterprise customer data collected through e-commerce credit evaluation, on the basis of large data and historical transaction basis for financing. (2) Through the combination of release and capital demanders of funds, acts as an intermediary role. Intermediary platform mainly has two modes: one is single providing information services, there is no capital absorption and lending situation, from small companies or the rest of the loan guarantee agencies two-way guarantee, realize a one-to-many characteristics, the second it is 
through the network to contact investors and demanders, adopt the many-to-many demand patterns, build money lending relationship between individual and individual. (3) Take the customer as the center was established through the Internet network marketing system, the traditional marketing model and network marketing model, to establish Shared financial platform, marketing mode to realize the interactive marketing. (4) Through the Internet to provide the required capital requirements, improve social services and to commercial bank online banking as the carrier network channel role into full play. In related traditional banking law of our country, the deposit rate upper limit and lower limit has certain limitation, and commercial banking and investment banking business separately, etc. Transferable payment orders account and transfer services, broke no pay interest of current deposit and savings deposits can't check rules, and money market accounts and certificates of deposit money market is to break the limitation of the deposit interest rate, our country at present are also gradually relax restrictions on bank interest rates and the emergence of shadow banking, make some instead of a huge increase in bank deposits, loans, interest rate marketization also gradually let go, to a certain extent which promoted the process of interest rate market [1].

Along with the appearance of the Internet financial tools, the traditional banking system will be unable to meet the needs of the financial markets to timely adjust. The connotation of Internet financial is to use the Internet technology makes everyone has the power and the means of social and economic participation in financial activities, financial services in information symmetry, gradually close to the effectiveness of the financial and democratization. The characteristics of the Internet makes financial service object to sink and in-depth and make direct financial more convenient, speed up into the financial times which is the promoter of financial reform. Financial is not based on one or some kind of main body of finance, but stressed that the essential difference between them is whether have the spirit of the Internet, pay attention to the customer experience which can rely on Internet technology for financial innovation or thought. They are on the way of thinking, management, guidance and customer group, significantly different in such aspects as disintermediation. Internet financial include the Internet, Internet financial refers to commercial banks, securities companies and insurance companies active or passive network marketing using Internet technology and integration of resources. Internet around but the nature of the financial, financial sector could not from the Internet and their own development and the integration of both is inevitable [2].

In this paper, we research on the development path of commercial banks under the influence of Internet finance. Traditional financial institutions themselves in active use of the Internet technology to improve service which will strengthen management, and accelerating transformation. The role of the Internet financial is to promote competition and adequately not only meet the diverse financial needs and more are to weaken the disadvantaged reliance on a single financial institution. In the next subsections, we will discuss the problems in detail.

\section{The Principles of Our Research}

The Basic Features of Internet Finance. Traditionally, the bank is one of the important channels for fund sales. Because many bank branches, its advantage in the consignment fee negotiations, but the balance of products such as treasure after rise, people the convenient and quick to through computers and mobile phones and other mobile terminal directly to buy financial products. Commercial banks, although also introduced a kind of balance of monetary fund product, but on the other hand, the balance of the treasure and other products with the advantages of ancestors is given priority to the bank's monetary fund products than on purchase convenience associated balance treasure and 
embedded WeChat financial management. Banking system, on the other hand, although monetary fund products can avoid the balance dominance and obtain fund management fee, but the expansion of the monetary fund products will further intensify bank deposits move, left bank in a dilemma situation. At the same time, with the balance of treasure products such as fashionable, people buy products through a network of recognition. Fund also increased sales through the network product promotion and it also has certain extrusion agency business in the commercial bank.

Social platform and electric business platform are accumulated the massive, unstructured data, covering the user details in aspects of capital changes, consumer spending and big data and the application of cloud computing technology is to dig the user experience law such as consumer preferences and consumption ability, undertake personalized products and services innovation, using the platform to implement the precision marketing. On product innovation, networks of small loan company may, according to the user on the Internet, the accumulation of credit data and transaction amount and frequency of historical transaction records and tailored to different interest rates, repayment and repayment of loans and the use of big data for credit evaluation. Credit by model calculation, real-time tracking control the risk capital businesses such as dynamic, greatly reduce the information asymmetry in the small micro enterprise financing and transaction costs. Big data and cloud computing also provide information and technical support for business model innovation which has sprung up a lot of examples in this respect. The advances of the Internet financial could be summarized as the follows. (1) Internet financial has low cost, convenient and fast advantages. To the market popular, Internet financial enterprise for small and medium-sized enterprises and provides the convenient financial transactions way to ordinary consumers. In a convenient, quick, participation and experience the basic demands, such as the recognition of the market. And financial business mainly to do business on the Internet, save the cost of large branches. Internet financial enterprises based on network technology, information processing technology, the corresponding time and credit guarantee deadline matching, simplify the procedure of risk management. (2) Internet financial has the information advantages. Internet financial enterprises with the accumulation of huge amounts of customer data, customer can more accurately find and mining. Rely on big data processing and data model, rapidly and accurately grasp the customer behavior characteristics, including customer's consumer behavior and credit rating, this for Internet financial enterprises to carry out the small micro financial business which provides the convenience. (3) The influence of commercial banks in the financial sector to expand. Micro finance is emerging in recent years, a kind of financial model, it is the smaller, shorter financial behavior [3-4].

The P2P Finance. P2P online and offline will be closer together. Traditional one-to-one offline mode between Banks and securities, trust, fund has developed and extended to the extreme, trying to break the monopoly of sharing revenue and into private funds to make a sound it has to have their own stage. The increase of the stage is gradually leaded to projects, especially high quality projects and capital is scarce, the traditional resource contention between platform and a new P2P platform began to increasingly intense at the same time also prompted online and offline are more closely linked. The development of the $\mathrm{P} 2 \mathrm{P}$ will not only depend on the platform itself, the project itself and the information channels or return of funds, but increasingly rely on guarantee strength. Early full pursuit of capital profitability starts assignment for security, competition for resources, especially of the scramble for money rather than the project resources indirectly increased the cost of financing, the demand for 
security to guarantee mechanism is introduced to further adding to the costs.

P2P business, Internet practitioners had wanted to punch killed, the spirit of the Internet and the characteristics of revising and transplant began to traditional high-profit industry highlands fire and originally the personnel engaged in the financial sector, in the new and old, tradition and innovation, risk and profit between suddenly lost its essence began to swing, also lost the principle. In short, high yield high risk must be required to undertake, high risk must be through the top was dissolved. No solid financial background and experience, only through the so-called law of large number and the spirit of the Internet to play in the Internet and finance, the result is only a flash in the pan. The current $\mathrm{P} 2 \mathrm{P}$ platform, copying, and even the same content of the interface, a city of original small loan company or investment company holds a lot of customer information, through a simple silver model can build a platform, even the background software can be paid directly to buy, others don't need to do business innovation can blaze. Now it seems that a lot of so-called P2P innovation is only to solve the problem of insufficient capital, the original small loan company small loan company has its own capital investment, can only choose a capital increase or bank loans, capital aside, the shareholders in now the economic environment, his lack of money, mostly by way of equity pledge to redeem part of the money, is not out, it is not easy. Now, if we want to long-term foothold in the $\mathrm{P} 2 \mathrm{P}$ market which must have or try to establish the following advantages. (1) Policy layout in advance, for early movers, improves software and hardware conditions. (2) As small loan companies for high-end talent poaching that absorb the bank from the bank, and understand marketing and risk control.

The Development Path of Commercial Banks. The emergence of the Internet financial and development purpose is not to replace traditional financial system, on the contrary, as a kind of market, Internet financial more appropriate in small, large quantity, standardization of financial products. Internet financial at present is not the extent to which eroded the market of commercial Banks, but to a certain extent, to fill the market blank. In some markets, of course, the Internet will financial size of financial institutions and the Internet financial companies back to the same starting line. Internet financial has brought challenges for the commercial banks at the same time which also provides a way for commercial Banks to speed up the reform and development of the power and pressure. The advantage of traditional financial institutions could be summarized as the follows. (1) Money creation function of the traditional commercial banking institutions and the position in payment and settlement system, the Internet financial in the short term is difficult to replace. These advantages are the result of the development of financial industry long-term evolution, but also by the recognition of the current legal system and supervision. The traditional commercial bank's core advantages, such as the national credit, regulatory protection, is a financial enterprise in a short period of time is very difficult to have Internet. (2) Commercial Banks in the financial business has a mature management model, rich industry experience and great business scale. To, financial services in large loans, commercial Banks have the advantage of a financial model can't have the Internet. Large, complex financial transactions which need advanced financial professional knowledge, as well as legal, accounting, credit evaluation, industry experts and other professionals to support. On the other hand, in the most basic loan, commercial banks can also provide bank acceptance bills of exchange. (3) The core of the commercial bank financial business data processing platform security and data processing capacity of the Internet financial management enterprise which has the payment and settlement, clearing, credit in areas such as perfecting the IT infrastructure. Internet 
financial model some of the innovations need to be tested in practice.

\section{Conclusion}

In this paper, we research on the development path of commercial banks under the influence of Internet finance. The Internet finance, not simply combining modern information technology and financial industry, but in the use of cloud technology, the Internet search engines, social networks and other tools, implementation of network information security on the basis of combination of traditional financial industry business and new business, meet the demand of information age people in the financial industry new emerging field. This new kind of financial model, not only to a certain extent, solve the past due to financial market information asymmetry financing difficult problem, at the same time also can through the Internet giant social network. Therefore, reform and update of the traditional commercial banks is necessary which illustrate the necessary meaning of our research.

\section{Acknowledgement}

This paper is supported by the soft science research plan on the project in Shaanxi province (NO. 2015KRM160). The project name is: the development of commercial banks under the background of Internet financial strategy research using the bank of China Shaanxi branch as the example.

\section{References}

[1] Zhao Y. Analysis of the current situation of the supply chain finance business of the commercial banks in China under the impact of the Internet Financial[J]. Economic Research Guide, 2014.

[2] Huang Y, Xing W, Polytechnic C A. Challenges and Countermeasures of Internet Finance to Traditional Commercial Banks[J]. Journal of Chengdu Aeronautic Polytechnic, 2014.

[3] Ma X. The Influence of Yu'e Bao on the Businesses of Commercial Banks[J]. Journal of Henan Institute of Science \& Technology, 2014.

[4] Dong J, Jiao D, Zhang X, et al. Customer Information Protection of Commercial Banks under the Background of Big Data Finance[J]. Journal of Engineering Studies, 2014. 